\title{
In vitro and In vivo Activity of Myrsine africana on Elastase Inhibition and Anti-wrinkle Activity
}

\author{
Namrita Lall, Navneet Kishore, Bianca Fibrich, Isa Anina Lambrechts \\ Department of Plant and Soil Sciences, University of Pretoria, Pretoria 0002, South Africa \\ Submitted: $14-04-2017$ \\ Revised: 18-07-2017 \\ Published: 13-11-2017
}

\begin{abstract}
Background: Myrsine africana (MA) is a plant traditionally used in South Africa to treat various diseases. Objective: The ethanolic extract of MA, was used for in vitro and in vivo studies to determine its elastase inhibitory activity. Materials and Methods: MA and its isolated compound, myrsinoside $B$, were tested in vitro for their elastase inhibitory activity. The MA extract was also evaluated for mutagenicity using two strains of Salmonella typhimurium (TA 98 and TA 100), microbial count, metal analysis, and stability. In vivo studies included irritancy and wrinkle reduction trials using Visioscan and Visioface. Results: The leaf extract showed good elastase inhibition with a $50 \%$ inhibitory concentration $\left(\mathrm{IC}_{50}\right)$ of $28.04 \mu \mathrm{g} / \mathrm{ml}$. Myrsinoside $B$ inhibited the elastase enzyme at an ${ }^{\prime} C_{50}$ of $4.68 \pm 0.34 \mu \mathrm{g} / \mathrm{ml}$. No colony growth observed during mutagenicity studies and it was concluded that MA ethanolic extract is a nonmutagen. MA extract was found to be a nonirritant during the patch test clinical trial. MA was found to contain negligible amounts of microorganisms and heavy metals. Gel cream containing MA crude extract was found to be stable for 2 years when kept at temperatures below $30^{\circ} \mathrm{C}$. In clinical trials (in vivo), it was found that the test product containing $5 \%$ ethanolic extract of MA was effective in reducing wrinkles after application 2 times a day for 14 days and 28 days compared to the placebo aqueous cream. Conclusion: MA is effective in reducing the appearance of wrinkles.

Key words: Antiwrinkle, elastase, Myrsine africana, myrsinoside B

\section{SUMMARY}

- This is a first time report of the elastase inhibitory potential of Myrsine africana and myrsinoside B and the anti-wrinkle potential of Myrsine africana

- Myrsine africana ethanolic extract effectively inhibited the elastase enzyme
\end{abstract}

- Myrsine africana was effective in in vivo studies to reduce the appearance of wrinkles after 14 days.

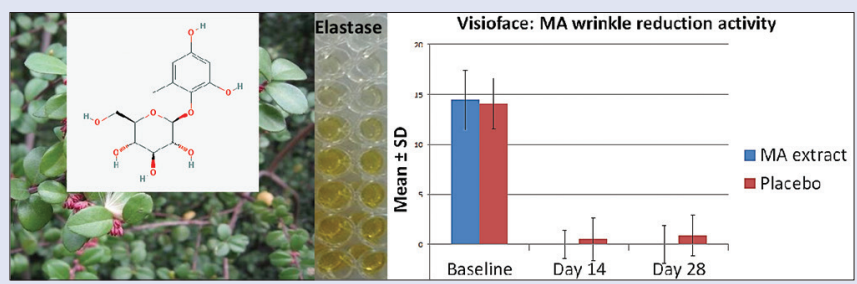

Abbreviations used: 4-NOO: 4-nitroquinoline, D14-BL: Baseline to day fourteen, D28-BL: Baseline to day twenty-eight, CFU: Colony forming units, $I C_{50}: 50 \%$ inhibitory concentration, MA: Myrsine africana, MOU: Measurement of uncertainty, $\mathrm{NaCl}$ : Sodium chloride, $\mathrm{NaH}_{2} \mathrm{PO}_{4} \cdot \mathrm{H}_{2} \mathrm{O}$ : Sodium phosphate monobasic monohydrate, SEM: Standard error of the mean, TA 98: Salmonella typhimurium strain 98, TA 100: S. typhimurium strain 100, TLC: Thin layer chromatography,

TMA: Total microbial activity, XVB salt:

Vogel-Bonner medium E.

Correspondence:

Prof. Namrita Lall,

Department Plant and Soil Science,

Private Bag X20,

Hatfield 0028, South Africa.

E-mail: namrita.lall@up.ac.za

DOI: 10.4103/pm.pm_145_17
Access this article online Website: www.phcog.com Quick Response Code:

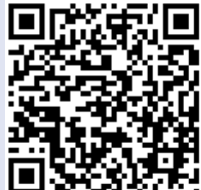

\section{INTRODUCTION}

Myrsine africana (MA) belonging to the Myrsinaceae family is a small shrub also known as the Cape Myrtle, African boxwood or Thakisa. The plant is indigenous to Macaronesia, Africa, and South Asia. It is found throughout South Africa, commonly in areas where summer and winter rainfall occurs. It grows naturally on rocky krantzes and forests. MA has dense, dark-green to red leaves and produces tiny bright purple berries. Heights of over $2 \mathrm{~m}$ can be reached and may be dense if pruned or grown in strong sunlight. The cream-colored flowers appear in spring, with the male flowers boasting red anthers. Separate shrubs produce either male or female flowers, with the female plants producing purple berries. ${ }^{[1,2]}$

MA has been found to have many traditional uses. The Southern Sotho administers it to rams to prevent them covering the ewes before the proper time. The Tswana and Kwena people used a decoction made from the leaves as a "blood purifier." ${ }^{[1,2]}$ In traditional medicine concoctions made from the bark, roots, and fruits together with other plants have been used as anthelmintics in humans and livestock. The plant is also traditionally used as an antibacterial agent. ${ }^{[3]}$ In Chinese folklore, it is traditionally used to treat diseases such as diarrhea, rheumatism, toothache, pulmonary tuberculosis, and for relieving hemorrhage. ${ }^{[4]}$ It is also used as a fragrance in tea, spices, carminative, appetizer, and flavoring agent. ${ }^{[5]} \mathrm{A}$ decoction of fresh leaves can be taken twice daily for 6-7 days, orally, for the treatment of scanty urination, skin allergies, boils, and to purify blood. ${ }^{[6]}$

Aging of the skin results from two main factors: Genetic programming and permanent actinic damage due to environmental stress (ultraviolet, detergents, mechanical shocks, etc.) with age, especially of people over 40 years, the elasticity of the skin is significantly decreased by elastase activity and that results in sagging. Histological examination reveals a thickened epidermis, an increased number of mast cells and hypertrophic cysts, the infiltration of inflammatory cells, the partial absence and aggregation of elastin fibers and a decrease in collagen

This is an open access article distributed under the terms of the Creative Commons Attribution-NonCommercial-ShareAlike 3.0 License, which allows others to remix, tweak, and build upon the work non-commercially, as long as the author is credited and the new creations are licensed under the identical terms.

For reprints contact: reprints@medknow.com

Cite this article as: Lall N, Kishore N, Fibrich B, Lambrechts IA. In vitro and In vivo activity of Myrsine africana on elastase inhibition and anti-wrinkle activity. Phcog Mag 2017;13:583-9. 
fibers. Biologically, elastase activity significantly increases with age resulting in reduced skin elasticity and in the appearance of wrinkles or stretch marks. Due to the significance of elastase in wrinkle formation of the skin, it is suggested that elastase inhibitors may be beneficial in control of aging of the skin. ${ }^{[7,8]}$

In the present assay, porcine pancreatic elastase was used as an enzyme source to set up the inhibition assay. The pancreatic elastase inhibitory activity was determined in vitro by spectrophotometric determination of the release of $\mathrm{p}$-nitroaniline from a synthetic substrate N-Succinyl-Ala-Ala-Ala-p-nitroanilide.

The aim of the present assay was to evaluate the elastase inhibitory potential of MA and its potential to reduce the appearance of wrinkles.

\section{MATERIALS AND METHODS}

\section{Materials}

Petroleum ether, chloroform, ethyl acetate, n-butanol, silica gel, thin layer chromatography (TLC) plates, dichloromethane, methanol, elastase (E.C.3.4.21.36) Type IV from porcine pancreas (E0258, Sigma, USA), N-Succinyl-Ala-Ala-Ala-p-nitroanilide (S4760, Sigma, USA) and the positive control ursolic acid (U001, Natural Remedies Pvt. Ltd., India), ethanol, Trizma hydrochloride (Tris- $\mathrm{HCl}$ buffer), dextrose, magnesium sulfate $\left(\mathrm{MgSO}_{4} \cdot \mathrm{H}_{2} \mathrm{O}\right)$, citric acid monohydrate, potassium phosphate (diabasic) anhydrous $\left(\mathrm{K}_{2} \mathrm{HPO}_{4}\right)$, sodium ammonium phosphate $\left(\mathrm{Na}_{2} \mathrm{NH}_{2} \mathrm{PO}_{4} \cdot 4 \mathrm{H}_{2} \mathrm{O}\right)$, Difco agar, XVB salt solution (Vogel-Bonner medium E) salt solution, $40 \%$ glucose, D-biotin, L-histidine, sodium chloride $(\mathrm{NaCl})$, oxoid nutrient broth number 2, sodium monobasic $\left(\mathrm{NaH}_{2} \mathrm{PO}_{4} \cdot \mathrm{H}_{2} \mathrm{O}\right)$, sodium diabasic $\left(\mathrm{Na}_{2} \mathrm{HPO}_{4} \cdot \mathrm{H}_{2} \mathrm{O}\right)$, oxoid nutrient broth, 4-nitroquinoline 1-oxide (4-NQO) and Euxyl PE 9010, sodium lauryl sulfate, aqueous cream, Pseudomonas aeruginosa, Staphylococcus aureus, Escherichia coli, Candida albicans and Aspergillus niger, S. typhimurium strains 98 and 100, Euxyl PE 9010.

\section{Plant collection}

The leaves of MA were collected during 2011 from the Manie van der Schijff Botanical Garden in Pretoria, South Africa.

\section{Preparation of ethanol extract}

Plant material (leaves and twigs) was shade dried for 2 weeks and then ground to a fine powder. The dried powder was macerated in distilled ethanol and extracted for $48 \mathrm{~h}$. The filtrate of the plant was collected after filtration with a Buchner funnel. The extract was then collected after the filtrate was put under reduced pressure using a rotary evaporator. The extract was kept in a cold room until further use. This extract was used to test for elastase inhibition and mutagenicity. The dry ethanolic leaf extract (300 mg) was dissolved in 70\% ethanol and used for irritancy, microbial and metal as well physiochemical and in vivo studies.

\section{Isolation of myrsinoside B}

The air-dried and powdered shoots $(2.3 \mathrm{~kg})$ were soaked in ethanol to get extract with continuous stirring on a rotatory shaker for 3 days. Dried ethanolic extract of the shoots ( $88 \mathrm{~g}$ ) was re-dissolved in ethanol and suspended in $800 \mathrm{ml}$ of distilled water. The water suspension was successively partitioned with petroleum ether, chloroform, ethyl acetate, and n-butanol. The organic layers were evaporated on a rotary evaporator to dryness at $40^{\circ} \mathrm{C}$ to give different fractions. The ethyl acetate fraction $(18.7 \mathrm{~g})$ was subjected to silica gel column using n-hexane-ethyl acetate-methanol-water, eluents. Similar fractions were pooled based on the TLC profile, which resulted in a total of seven major fractions.
Major fraction $2(1.25 \mathrm{~g})$ was subjected to a silica gel column with an eluent of dichloromethane:methanol in increasing polarity $(0 \%-100 \%)$. Subfractions 2-4 (0.5 g) were chromatographed again on silica gel using dichloromethane:methanol (7:1), which afforded the compound myrsinoside B (257 mg, $0.0111 \%$, of dry plant material).

\section{Elastase inhibition assay \\ Sample preparation}

Sample stock solutions of $500 \mu \mathrm{g} / \mathrm{ml}$ were prepared from the MA leaf extract and the compound in methanol. The test sample was added to Tris- $\mathrm{HCl}$ buffer in a 96-well microtiter plate to a total volume of $200 \mu \mathrm{l}$ and serially diluted.

\section{Elastase inhibition assay on ethanolic leaf extract and the compound myrsinoside B (in vitro)}

Elastase inhibition assay was carried out as previously described with slight modifications. ${ }^{[9]}$ In brief, a preincubation mixture contained 100 mM Tris-HCl buffer, $\mathrm{pH}$ 8.0/vehicle buffer/positive control/test sample of various concentrations and $4.942 \mathrm{mU}$ of elastase enzyme. The plate was mixed and preincubated at $37^{\circ} \mathrm{C}$ for $15 \mathrm{~min}$. Following preincubation, the substrate (N-Succinyl-Ala-Ala-Ala-p-nitroanilide) was added to a final concentration of $0.338 \mathrm{mM}$ and the plate was mixed and incubated at $37^{\circ} \mathrm{C}$ for $30 \mathrm{~min}$. The absorbance was measured at $405 \mathrm{~nm}$ in a microplate reader (Versamax, Molecular Devices, Sunnyvale, CA 94089 USA). A control reaction was carried out without the test sample. Ursolic acid was used as the positive control.

The $\%$ inhibition of the enzyme was calculated as follows:

$\%$ inhibition $=\frac{\text { Absorbance }(\text { control })-\text { Absorbance }(\text { test })}{\text { Absorbance }(\text { control })} \times 100$

$50 \%$ inhibitory concentration $\left(\mathrm{IC}_{50}\right.$ ) was calculated using log-probit analysis.

\section{Mutagenicity}

Preparation of glucose solution (40\%)

One liter of distilled water was added to $400 \mathrm{~g}$ of dextrose in $1 \mathrm{~L}$ flask. The solution was placed on a magnetic stirrer until clear. The flask was then autoclaved for $20 \mathrm{~min}$ at $121^{\circ} \mathrm{C}$. The solution was then stored at $4^{\circ} \mathrm{C}$ (refrigerated).

\section{Preparation of XVB salt solution (Vogel-Bonner medium E [X50])}

Six hundred and fifty milliliters of warm distilled water was added to $10 \mathrm{~g}$ of magnesium sulfate $\left(\mathrm{MgSO}_{4} \cdot \mathrm{H}_{2} \mathrm{O}\right), 100 \mathrm{~g}$ of citric acid monohydrate, $500 \mathrm{~g}$ potassium phosphate (diabasic) anhydrous $\left(\mathrm{K}_{2} \mathrm{HPO}_{4}\right)$, and $175 \mathrm{~g}$ of sodium ammonium phosphate $\left(\mathrm{Na}_{2} \mathrm{NH}_{2} \mathrm{PO}_{4} \cdot 4 \mathrm{H}_{2} \mathrm{O}\right)$ in a $2 \mathrm{~L}$ flask on a magnetic stirrer, making sure that before each new salt was added the former was completely dissolved. Distilled water was then added so that the final volume was $1 \mathrm{~L}$. The solution was then autoclaved for $30 \mathrm{~min}$ at $121^{\circ} \mathrm{C}$, thereafter allowed to cool and stored in the dark at room temperature.

\section{Preparation of the glucose minimal agar plates}

Fifteen grams of Difco agar was added to $900 \mathrm{ml}$ of distilled water, after which solution was then autoclaved for $30 \mathrm{~min}$ at $121^{\circ} \mathrm{C}$ and allowed to cool to approximately $65^{\circ} \mathrm{C} .20 \mathrm{ml}$ of the sterile XVB salt solution was then added to the flask ensuring thorough mixing. Fifty mililiters of the $40 \%$ glucose solution was then added to the same flask, ensuring thorough mixing. The mixture was then dispensed into $100 \times 15 \mathrm{~mm}$ petri plates $( \pm 25-30 \mathrm{ml}$ of agar in each plate). The plates were then allowed to solidify before being placed in sealed plastic bags and stored at $4^{\circ} \mathrm{C}$ overnight. The following day the plates were allowed to reach room temperature before being used in the test. 


\section{Preparation of the histidine/biotin solution (0.5 mM)}

One liter of distilled water was brought to the boil and $124 \mathrm{mg}$ of D-biotin and $96 \mathrm{mg}$ of L-histidine were added to the water. The biotin took slightly longer to dissolve.

\section{Preparation of the supplemented top agar}

Six grams of agar and $6 \mathrm{~g}$ of $\mathrm{NaCl}$ were added to $900 \mathrm{ml}$ of distilled water. The mixture was heated in an autoclave for $10 \mathrm{~min}$ to melt the agar. One hundred mililiters of the previously prepared histidine/biotin solution was added to the jar. The top agar was labeled and autoclaved for a further $30 \mathrm{~min}$ and stored at room temperature in the dark.

\section{Preparation of nutrient broth for growth of tester strains}

Twenty-five grams of oxoid nutrient broth number 2 was added to $1 \mathrm{~L}$ of distilled water and stirred until the broth was dissolved. Fifty milliliters was dispensed into an Erlenmeyer flask and autoclaved for $20 \mathrm{~min}$. The solution was cooled and stored in a dark area at room temperature.

\section{Preparation of sodium phosphate buffer $0.1 \mathrm{mM}, \mathrm{pH} 7.4$}

Thirteen point $8 \mathrm{~g}$ of $\mathrm{NaH}_{2} \mathrm{PO}_{4} \cdot \mathrm{H}_{2} \mathrm{O}$ was added to $1 \mathrm{~L}$ of water (sodium monobasic, $0.1 \mathrm{M}$ ). Fourteen point $2 \mathrm{~g}$ of $\mathrm{Na}_{2} \mathrm{HPO}_{4} \cdot \mathrm{H}_{2} \mathrm{O}$ was added to $1 \mathrm{~L}$ of water (sodium diabasic, $0.1 \mathrm{M}$ ). One hundred and twenty milliliter of sodium diabasic was added to $880 \mathrm{ml}$ of monobasic solution and mixed. The $\mathrm{pH}$ was adjusted to 7.4 by the addition of the $0.1 \mathrm{M}$ sodium diabasic solution. The buffer was autoclaved for $30 \mathrm{~min}$ at $121^{\circ} \mathrm{C}$. The bottle was allowed to cool before being stored at room temperature in a dark place.

\section{Method for test plates}

Nine plates were used for the sample because 3 concentrations were tested and each concentration was done in triplicate. One hundred microliters of bacterial stock were incubated in $20 \mathrm{ml}$ of oxoid nutrient broth for $16 \mathrm{~h}$ at $37^{\circ} \mathrm{C}$ on a rotative shaker. Zero point $1 \mathrm{ml}$ of this overnight culture was added to $2.0 \mathrm{ml}$ of top agar (containing traces of biotin and histidine) together with $0.1 \mathrm{ml}$ test solution (test sample, solvent control, or positive control) and $0.5 \mathrm{ml}$ phosphate buffer. The top agar mixture was poured over the surface of a minimal agar plate and incubated for $48 \mathrm{~h}$ at $37^{\circ} \mathrm{C}$. After incubation, the number of revertant colonies (mutants) was counted. All cultures were made in triplicate (except the solvent control where five replicas were made). Toxicity can be checked by investigation of the background layer of bacteria. The absence of toxicity was examined by observing the background bacterial growth, which should be normally present. The positive control used in this study was $4-\mathrm{NQO}$ at a concentration of $2 \mu \mathrm{g} / \mathrm{ml}$.

\section{Irritancy testing (patch test), preservative challenge test and physiochemical analysis}

Sample was applied on the inner forearm of 20 volunteers aged between 19 and 65 years using patch discs for $24 \mathrm{~h}$ to determine irritancy. Visual assessments of the areas were made after 24, 48, 72, and $96 \mathrm{~h}$. Any reaction was graded as a score of $0,0.5,1,2,3$, and 4 , where 0 represented a no response and 4 a fiery redness, papules, edema or bullae. The forearm of each volunteer included a positive control of sodium lauryl sulfate solution $(1 \mathrm{~g} / 100 \mathrm{ml})$ and a negative control of demineralized water.

For the preservative challenge test, the sample was tested in accordance with the United States Pharmacopeia 31 method, ${ }^{[10]}$ using: $P$. aeruginosa, S. aureus, E. coli, C. albicans and A. niger in a preservative challenge test. The preservative Euxyl PE 9010 was used as the positive control.

The physiochemical analysis was carried out as follows:

\section{Determination of odor and color of the extracts}

The odor and color (appearance) of the MA extract was recorded visually.

\section{Determination of $\mathrm{pH}$}

The $\mathrm{pH}$ of the MA extract was determined using a $\mathrm{pH}$ meter. The $\mathrm{pH}$ meter was calibrated using the standard $\mathrm{pH} 4$ and 7 standard solutions. The electrode was then submerged in the extracts and recorded.

\section{Determination of specific gravity of the extracts}

The specific gravity of the extracts was determined using a pycnometer. The pycnometer was weighed while it was empty. It was then filled with distilled water and weighed again. The weight before filling was subtracted from the weight after filling and divided by the capacity $(\mathrm{ml})$ of the pycnometer to give a specific gravity in $\mathrm{g} / \mathrm{ml}$.

\section{Determination of viscosity of gel cream formulations}

Determination of the viscosity of the MA was done using a viscometer (Brookfield). The size 5 spindle at a speed of $5 \mathrm{rpm}$ was used to obtain a viscometer reading. The viscometer reading was multiplied by the factor and the gel cream viscosity was recorded in centiposes.

\section{Determination of refractive index of extracts}

The refractive index was determined using a refractometer. A glass Pasteur Pipette was used to suck up 2-3 ml of the plant extract. The plant extract was placed on the refractometer lens and the refractive index was determined at $25^{\circ} \mathrm{C}$.

\section{Stability test Myrsine africana ethanolic crude extract}

Two hundred milliliters of extract was placed in four $250 \mathrm{ml}$ glass jars. The jars were labeled and stored at their specific temperatures. The preservative Euxyl PE 9010 was added to each jar at $1 \%$. The stability test was performed at $5^{\circ} \mathrm{C}, 25^{\circ} \mathrm{C}, 40^{\circ} \mathrm{C}$, and $50^{\circ} \mathrm{C}$. Various parameters of the extract stored at each temperature were measured after 1, 2, 4, 8 , and 12 weeks. The parameters included appearance and odor which were both recorded sensory. $\mathrm{pH}$ was measured using a $\mathrm{pH}$ meter. Specific gravity was measured using a pycnometer was only measured initially and at the final 12 weeks interval. For all the samples, the initial result for each parameter was recorded and then for all subsequent intervals recordings were taken as well.

\section{Gel cream and Myrsine africana ethanolic extract}

Two hundred milliliters of cream gel was placed in four $250 \mathrm{ml}$ glass jars. The jars were labeled and stored at their specific temperatures. The stability test was performed at $5^{\circ} \mathrm{C}, 25^{\circ} \mathrm{C}, 40^{\circ} \mathrm{C}$, and $50^{\circ} \mathrm{C}$. Various parameters of the cream gel were stored at each temperature were measured after 1,2 , 4,8 , and 12 weeks. The parameters included appearance and odor which were recorded using sensory methods. The $\mathrm{pH}$ was measured using a $\mathrm{pH}$ meter. Specific gravity was measured using a pycnometer and viscosity was measured using a viscometer. For all the samples, the initial result for each parameter was recorded and then for all subsequent intervals recordings were taken as well.

\section{Clinical trials on $M$. africana ethanolic leaf extract (in vivo)}

The dry ethanolic leaf extract $(300 \mathrm{mg}$ ) was dissolved in $70 \%$ ethanol $(40 \mathrm{ml})$, where after the concentration of the product was made with a $5 \%$ dilution.

A group of 22 subjects were recruited and the procedure of testing was explained to them verbally, and a form of consent and medical history was 
signed by each subject. Personal details and each subject's assessment of their own skin type were recorded. Color photographs were taken at each time interval to serve as a recording of the study conducted. All subjects were instructed to rest for $20 \mathrm{~min}$ before any testing was conducted. The designated left and right side of the test site was cleansed with a standard eye make-up remover and allowed to air dry for $3 \mathrm{~min}$. The temperature and relative humidity were recorded during the time of the study. No test sites were demarcated on the face as Complete Skin Investigation (Courage+Khazaka electronic $\mathrm{GmbH}$, Cologne, Germany) software needed the complete wrinkle length for analysis. Product application was randomized according to the test substance sequence. A photo was taken of the region of interest for the Visioscan analysis as well. An operator trained the test subjects in applying the test products evenly to the test sites, according to the test substance sequence. Subjects were restricted from using any topical products or any medication not approved by the study sponsor for the duration of the study. Baseline (BL) photos were taken before application of test products and again on day 14 (D14) and day 28 (D28) to serve as a recording of the study. Subjects were given test product to apply twice a day. Subjects returned to the testing facility on D14 as well as D28 after baseline procedure. A placebo of aqueous cream was also used.

The Visioscan and Visioface were gently sterilized with $70 \%$ ethanol and a tissue between each reading.

\section{Statistical analysis}

The $t$-test was used to determine whether the given treatment during in vivo studies had a significant effect on a population. Statistically significant differences between variables were reported by a significant value $P$. The value of $P \leq 0.05$ was considered to have a statistically significant difference at the $5 \%$ level of significance.

\section{RESULTS}

\section{Elastase inhibition assay on ethanolic leaf extract of Myrsine africana and compound}

The leaf extract for MA was evaluated for its elastase inhibitory activity using the elastase inhibition assay. The assay is based on the release of p-nitroaniline from N-Succinyl-Ala-Ala-Ala-p-nitroanilide that is measured spectrophotometrically. The ethanolic extract of MA showed promising elastase inhibitory activity with an $\mathrm{IC}_{50}$ of $28.04 \mu \mathrm{g} / \mathrm{ml}$ [Table 1].

The isolated compound myrsinoside B was further evaluated for its elastase inhibitory activity and found to have an $\mathrm{IC}_{50}$ of $4.68 \pm 0.34 \mu \mathrm{g} / \mathrm{ml}$ [Table 1].

\section{Mutagenicity}

The ethanolic extract of MA was applied to two different strains of bacteria according to the number of colonies. According to the results obtained MA did not display any mutagenic effects in either TA 98 or TA 100 strains of S. typhimurium [Table 2]. MA did not display a ratio of 2 or higher in terms of revertants and no dose response curve was observed. The number of colonies observed may have been affected by the possibility that MA has anti-bacterial properties.

\section{Microbial count, metal analysis, and irritancy patch test}

The microbial count and metal analysis have been conducted by Swift Silliker and Microchem Specialized Lab Services, respectively.

The total microbial activity was found to have no activity since no growth of microbes was observed [Table 3]. Furthermore, no growth of yeast or mold was observed for MA ethanolic extract.

Low levels the heavy metals, arsenic, cadmium, mercury, and lead were observed for MA ethanolic extract [Table 4].

The leaf extract of MA was found to be nonirritant since the irritancy potential was found to be $-9.00 \%$ compared to the positive control sodium lauryl sulfate with an irritancy potential of $100 \%$ [Table 5].

\section{Preservative challenge test}

The growth of organisms P. aeruginosa, S. aureus, E. coli, C. albicans and $A$. niger was negligible when MA ethanolic extract together with a standard preservative was exposed to these organisms. This is an indication that MA ethanolic extract passed the preservative challenge test [Table 6].

\section{Physiochemical analysis}

The physiochemical results for MA can be found in Table 7.

\section{Stability test}

Results taken at week 0 were compared to that of observations at the end of 12 weeks. We expect to see a smaller change in the extracts at the lower temperatures and more adverse effects in the samples stored at the extreme temperatures. The initial $\mathrm{pH}$ value for the ethanolic $\mathrm{MA}$ extract was 5.28 and dropped slightly to $4.99,4.97,5.03$, and 5.12 for the $5^{\circ} \mathrm{C}, 25^{\circ} \mathrm{C}, 40^{\circ} \mathrm{C}$, and $50^{\circ} \mathrm{C}$ samples, respectively [Table 8]. From the results, it looks like the drop in $\mathrm{pH}$ is time-and temperature-related,

Table 1: 50\% inhibitory concentration of Myrsine africana, compound myrsinoside B and the positive control ursolic acid in the elastase inhibition assay

\begin{tabular}{|c|c|c|c|c|c|c|c|}
\hline \multicolumn{4}{|c|}{ MA ethanolic extract } & \multicolumn{4}{|c|}{ Myrsinoside B } \\
\hline Sample & $\begin{array}{c}\text { Concentration } \\
(\mu \mathrm{g} / \mathrm{ml})\end{array}$ & $\begin{array}{l}\text { Percentage } \\
\text { inhibition } \\
\text { (mean } \pm \text { SEM) }\end{array}$ & $\begin{array}{c}\mathrm{IC}_{50}(\mu \mathrm{g} / \mathrm{ml}) \\
(95 \% \mathrm{Cl})\end{array}$ & Sample & $\begin{array}{c}\text { Concentration } \\
(\mu \mathrm{g} / \mathrm{ml})\end{array}$ & $\begin{array}{l}\text { Percentage } \\
\text { inhibition } \\
\text { (mean } \pm \text { SEM) }\end{array}$ & $\begin{array}{c}\mathrm{IC}_{50}(\mu \mathrm{g} / \mathrm{ml}) \\
(95 \% \mathrm{Cl})\end{array}$ \\
\hline \multirow{5}{*}{$\begin{array}{l}\text { Ursolic acid } \\
\text { (positive control) }\end{array}$} & 5 & $13.22 \pm 2.25$ & $40.58(30.10-64.28)$ & Ursolic acid & 2.5 & $10.64 \pm 0.32$ & $20.80(16.51-27.53)$ \\
\hline & & & & (reference Inhibitor) & 5 & $21.10 \pm 0.53$ & \\
\hline & 10 & $24.13 \pm 4.50$ & & & 10 & $40.07 \pm 1.22$ & \\
\hline & 25 & $41.43 \pm 0.92$ & & & 25 & $58.85 \pm 0.17$ & \\
\hline & 50 & $53.16 \pm 0.56$ & & & 50 & $62.14 \pm 1.18$ & \\
\hline \multirow[t]{7}{*}{ MA } & 1 & $4.29 \pm 2.43$ & $28.04(22.52-35.06)$ & Myrsinoside B & 3.125 & $43.72 \pm 3.98$ & $4.68(3.547-7.222)$ \\
\hline & 5 & $22.87 \pm 9.82$ & & & 6.25 & $50.54 \pm 1.62$ & \\
\hline & 10 & $25.21 \pm 1.55$ & & & 12.5 & $74.33 \pm 2.99$ & \\
\hline & 25 & $53.36 \pm 4.78$ & & & 25 & $81.09 \pm 1.08$ & \\
\hline & 50 & $64.58 \pm 3.57$ & & & 50 & $84.64 \pm 1.27$ & \\
\hline & 100 & $73.36 \pm 1.96$ & & & 100 & $92.83 \pm 1.33$ & \\
\hline & 250 & $81.19 \pm 0.91$ & & & 200 & $91.58 \pm 1.39$ & \\
\hline
\end{tabular}

CI: Confidence interval; MA: Myrsine africana; $\mathrm{IC}_{50}: 50 \%$ inhibitory concentration; SEM: Standard error of mean 
as the samples stored at accelerated conditions of temperature show a slower drop than the samples stored at ambient and $5^{\circ} \mathrm{C}$. The specific gravity of the extracts which was only performed at the end of the 12 weeks interval had an initial value of $0.9848 \mathrm{~g} / \mathrm{ml}$ and dropped to $0.853,0.782,0.816$, and $0.850 \mathrm{~g} / \mathrm{ml}$ for the $5^{\circ} \mathrm{C}, 25^{\circ} \mathrm{C}, 40^{\circ} \mathrm{C}$, and $50^{\circ} \mathrm{C}$ samples, respectively. This could most likely be due to sedimentation of the sample [Table 8].

Darkening of the product was recorded from the first week of storage at elevated temperatures and after 12 weeks at ambient conditions. The darkening of the product is due to the extract, and the overall efficacy of the product may be affected [Table 8]. The darkening may be just a physical change or a chemical change due to the temperature. However, darkening of products using extract is a normal occurrence. $\mathrm{pH}$ and viscosity show a drop in the values at accelerated conditions of temperature, but these will not affect the

Table 2: Average amount of colonies of Salmonella typhimurium observed at the indicated concentrations of Myrsine africana

\begin{tabular}{lcc}
\hline \multirow{2}{*}{$\begin{array}{l}\text { Concentration of test sample } \\
(\mathrm{mg} / \mathrm{ml})\end{array}$} & \multicolumn{2}{c}{ Number of colonies } \\
\cline { 2 - 3 } & TA 98 & TA 100 \\
\hline 5 & $18.67 \pm 1.15$ & $103.33 \pm 2.52$ \\
0.5 & $20.00 \pm 3.46$ & $105.33 \pm 1.53$ \\
0.05 & $15.33 \pm 2.08$ & $104.00 \pm 3.00$ \\
4 -NQO (positive control) & $168.33 \pm 9.81$ & $438.67 \pm 9.07$ \\
Blank & $26.00 \pm 3.46$ & $112.40 \pm 3.65$ \\
\hline
\end{tabular}

NQO: 4-nitroquinoline 1-oxide

Table 3: Microbial count of Myrsine africana ethanolic extract

\begin{tabular}{lllc}
\hline Test type & Method number & Result & Limits \\
\hline TMA & SWJM 35 & No growth CFU/ml & N/A \\
Yeast & SWJM 50 & No growth CFU/ml & N/A \\
Mould & SWJM 50 & No growth CFU $/ \mathrm{ml}$ & N/A \\
\hline
\end{tabular}

TMA: Total microbial activity; CFU: Colony forming units; N/A: Not applicable

Table 4: Heavy metal analysis of Myrsine africana ethanolic extract

\begin{tabular}{lcc}
\hline Test type & MOU (\%) & Result \\
\hline Arsenic $(\mathrm{mg} / 100 \mathrm{~g})$ & 9.77 & $<0.003$ \\
Cadmium $(\mathrm{mg} / 100 \mathrm{~g})$ & 5.40 & $<0.001$ \\
Mercury $(\mathrm{mg} / 100 \mathrm{~g})$ & 7.94 & $<0.010$ \\
Lead $(\mathrm{mg} / 100 \mathrm{~g})$ & 6.22 & $<0.005$ \\
\hline
\end{tabular}

MOU: Measurement of uncertainty

Table 5: Irritancy patch test results after $96 \mathrm{~h}$ for Myrsine africana

\begin{tabular}{|c|c|c|c|c|c|}
\hline Test product name & $\begin{array}{c}\text { Average } \\
\text { value }\end{array}$ & $\begin{array}{l}\text { Average } \\
\text { score }\end{array}$ & Number of subjects with reactions after $48 \mathrm{~h}$ & $\begin{array}{c}\text { Irritancy } \\
\text { potential (\%) }\end{array}$ & Irritancy \\
\hline MA ethanolic extract & 0.21 & 0.54 & 6 & -9.00 & Nonirritant \\
\hline Sodium lauryl sulphate (positive control) & 0.54 & 1.03 & 12 & 100 & Irritant \\
\hline
\end{tabular}

MA: Myrsine africana

Table 6: Preservative challenge test of Myrsine africana ethanolic extract against Pseudomonas aeruginosa, Staphylococcus aureus, Escherichia coli, Candida albicans and Aspergillus niger

\begin{tabular}{lllll}
\hline \multirow{2}{*}{$\begin{array}{l}\text { Exposure time (number of viable } \\
\text { organisms added at zero time) }\end{array}$} & \multicolumn{4}{c}{ Number of organisms recovered per ml/g } \\
\cline { 2 - 5 } & Escherichia coli & Pseudomonas aeruginosa & Staphylococcus aureus & $\begin{array}{l}\text { Candida albicans } \\
3.1 \times 10^{6}\end{array}$ \\
\hline 7 days & $8.8 \times 10^{6}$ & $8.4 \times 10^{6}$ & $1.0 \times 10^{6}$ & Aspergillus niger \\
14 days & NEG & NEG & NEG & NEG \\
21 days & NEG & NEG & NEG & NEG \\
28 days & NEG & NEG & NEG & NEG \\
\hline
\end{tabular}

NEG: No tested organism recovered overall product performance.

Based on the above results, a 2 years shelf life can be predicted for this product. The product should be stored away from direct sunlight and at temperatures below $30^{\circ} \mathrm{C}$.

\section{Clinical trials on Myrsine africana ethanolic leaf extract (in vivo) \\ Visioscan - wrinkle}

A $t$-test was performed to compare the test product sites and the untreated control sites at baseline (thus before application of test products) and no statistically significant difference was found between the two test sites on a $5 \%$ level of confidence. A $t$-test was performed to determine the treatment effect by comparing the average difference values between D14-BL of the test product and the placebo control sites, and there was no statistical significance difference on a $5 \%$ level of confidence. A $t$-test was performed to determine the treatment effect by comparing the average difference values between D28-BL of the test product and the placebo control sites, and there was a statistical significance difference on a $5 \%$ level of confidence. The values for the MA ethanolic extract were significantly lower than the values for the placebo (aqueous cream) [Table 9].

\section{Visioface (CSI) - wrinkle}

A $t$-test was performed to compare the test product sites, and the untreated control sites at baseline (thus before application of test products) and no statistically significant difference was found between the two test sites on a $5 \%$ level of confidence. A $t$-test was performed to determine the treatment effect by comparing the average difference values between D14-BL of the test product and the placebo control sites, and there was a statistical significance difference on a $5 \%$ level of confidence. The values for the MA extract were significantly lower than the values for the placebo. A $t$-test was performed to determine the treatment effect by comparing the average difference values between D28-BL of the test product and the placebo control sites, and there was a statistical significance difference on a $5 \%$ level of confidence. The values for the MA extract were significantly lower than the values for the placebo [Table 9].

\section{DISCUSSION AND CONCLUSION}

Skin ageing and the appearance of wrinkles is a frequent dermatological concern. Several synthetic skin care products are available to prevent the appearance of wrinkles. The active ingredients in these products include 
sodium Laureth sulfate, diethanolamine, and monoethanolamine. However, a number of adverse effects such as allergic contact dermatitis have been associated with the use of such products. ${ }^{[11]}$ Therefore, there is a growing need for safe alternative products to reduce the development and appearance of wrinkles. Dermal elastic fibers play a significant role in skin elasticity. Previous studies have found a relationship between the degradation of elastic fibers and an increase in elastase enzyme activity during ultraviolet B irradiation. These results suggested that elastase significantly altered the three-dimensional structure of the elastic fibers, contributing to wrinkle formation. ${ }^{[12]}$

This study is a first time report of the elastase inhibitory and wrinkle reduction potential of MA.

After performing the elastase inhibitory assay, it was determined that the ethanolic leave extract of MA showed promising elastase inhibitory activity. The isolated compound myrsinoside $\mathrm{B}$ was found to have an $\mathrm{IC}_{50}$ of $4.68 \pm 0.34 \mu \mathrm{g} / \mathrm{ml}$ [Table 1].

It can be concluded that the ethanolic leaf extract of MA inhibited the growth of $S$. typhimurium and is therefore considered not to be mutagenic.

Medicinal plants may be contaminated with a broad range of microbial contaminants, such as bacteria, fungi and viruses. This is why it has become important to assess microbial load of medicinal plants for quality control purposes. ${ }^{[11]}$ No microbial growth was observed for MA

Table 7: Physiochemical analysis of Myrsine africana ethanolic extract

\begin{tabular}{ll}
\hline Physiochemical parameter & Value \\
\hline $\mathrm{pH}$ & 5.28 \\
Viscosity & $1 \mathrm{cP}$ \\
$\mathrm{RI}$ & 1.35134 \\
Appearance & Dark brown, clear liquid \\
Loss of weight on drying & $50 \%$ \\
Odour & Characteristic, Berry-juice like \\
Solubility & Soluble in water \\
SG & 0.9848 \\
\hline
\end{tabular}

RI: Refractive index; SG: Specific gravity and it was concluded that the sample contains an amount below the limit. Toxic metals are defined as those which have no known function in the body and once present are harmful. These toxic metals have become a great concern as they are the causative agent of illness, aging and even genetic defects. ${ }^{[13]}$ It was found that MA ethanolic extract contained an amount below the limit of heavy metals allowed. According to clinical studies, the ethanolic extract of MA was found to be a nonirritant on human skin.

No significant growth was observed of the test organisms: P. aeruginosa, $S$. aureus, E. coli, C. albicans and A. niger during the preservative challenge test.

The physiochemical parameters that were tested substantiated the potential use of MA in a cosmeceutical for the treatment of wrinkles.

It was concluded through accelerated stability testing that cream gel containing MA ethanolic crude extract had a shelf life of 2 years when stored away from direct sunlight at temperatures below $30^{\circ} \mathrm{C}$.

Previous studies have reported MA to be nontoxic toward mouse melanocytes (B16-F10) at the highest concentration tested of $100 \mu \mathrm{g} / \mathrm{ml} .^{[14]}$ It was proposed that plant extracts should be considered to have moderate toxicity toward non-cancerous cell lines with in $\mathrm{IC}_{50}$ value above $100 \mu \mathrm{g} / \mathrm{ml}$. An $\mathrm{IC}_{50}$ between 300 and $1000 \mu \mathrm{g} / \mathrm{ml}$ were proposed to be considered to have a low toxicity toward non-cancerous cell lines. ${ }^{[15]}$

Visioface works on the whole wrinkle length, whereas Visioscan only works on sections of the wrinkle. In the clinical trials, it was found that for the Visioscan (wrinkle) that the MA ethanolic extract was effective in reducing wrinkles after D28 of consecutive application (twice a day) when compared to the placebo control (aqueous cream). The Visioface - CSI (wrinkle) it was found that the MA extract was effective in reducing wrinkles after D14 and D28 of consecutive application (twice a day) when compared to the placebo control. Since Visioface looked at each subject's Crow's feet area in a whole, therefore considering depth and length of wrinkle, it can be concluded that MA passed wrinkle tests on D14.

It can be concluded that MA has the potential to be used for the prevention and treatment of wrinkles associated with aging.

Table 8: Stability test of Myrsine africana ethanolic crude extract and gel cream containing Myrsine africana ethanolic crude extract

\begin{tabular}{|c|c|c|c|c|c|}
\hline \multirow{3}{*}{$\begin{array}{l}\text { Parameters } \\
\text { observed }\end{array}$} & \multirow{3}{*}{$\begin{array}{c}\text { Storage } \\
\text { conditions }\left({ }^{\circ} \mathrm{C}\right)\end{array}$} & \multicolumn{2}{|c|}{ MA ethanolic extract } & \multicolumn{2}{|c|}{ Gel cream } \\
\hline & & \multicolumn{2}{|c|}{ Storage intervals } & \multicolumn{2}{|c|}{ Storage intervals } \\
\hline & & Week 0 & Week 12 & Week 0 & Week 12 \\
\hline & 25 & red tint) & Complied & & Darker than standard \\
\hline & 40 & & Complied & & Darker than standard \\
\hline & 50 & & Complied & & Darker than standard \\
\hline & 40 & & Strong alcohol odour & & Complied \\
\hline & 50 & & Strong alcohol odour & & Complied \\
\hline \multirow[t]{4}{*}{$\mathrm{pH}\left(25^{\circ} \mathrm{C}\right)$} & 5 & 5.28 & 4.99 & 6.07 & 5.84 \\
\hline & 25 & & 4.97 & & 5.95 \\
\hline & 40 & & 5.03 & & 5.91 \\
\hline & 50 & & 5.12 & & 5.80 \\
\hline Viscosity $\left(25^{\circ} \mathrm{C}\right)$ & 5 & N/A & N/A & $45600 \mathrm{cPs}$ & 48000 \\
\hline & 25 & & 0.782 & & 0.965 \\
\hline & 40 & & 0.816 & & 0.972 \\
\hline & 50 & & 0.850 & & 0.971 \\
\hline
\end{tabular}

SG: Specific gravity; N/A: Not available 
Table 9: Comparison of Visioscan (wrinkle) and Visioface - Complete skin investigation (wrinkle) values for the test product Myrsine africana ethanolic extract (70\% ethanol) compared to the placebo control, aqueous cream

\begin{tabular}{lccc}
\hline Days & $\begin{array}{c}\text { MA ethanolic } \\
\text { extract }\end{array}$ & Placebo & $P$ \\
\hline Baseline & & & \\
$\quad$ Visioscan (wrinkle) & $68.24 \pm 10.39$ & $65.56 \pm 7.43$ & 0.160 \\
$\quad$ Visioface - CSI (wrinkle) & $14.45 \pm 2.98$ & $14.10 \pm 2.51$ & 0.344 \\
Day 14-baseline & & & \\
$\quad$ Visioscan (wrinkle) & $0.13 \pm 5.92$ & $-0.46 \pm 5.07$ & 0.360 \\
$\quad$ Visioface - CSI (wrinkle) & $-1.15 \pm 1.39$ & $0.50 \pm 2.14$ & 0.002 \\
Day 28-baseline & & & \\
$\quad$ Visioscan (wrinkle) & $-2.74 \pm 7.49$ & $1.16 \pm 5.94$ & 0.026 \\
$\quad$ Visioface - CSI (wrinkle) & $-2.20 \pm 1.91$ & $0.90 \pm 2.05$ & $<0.001$ \\
\hline
\end{tabular}

Mean \pm SD. MA: Myrsine africana; SD: Standard deviation; CSI: Complete Skin Investigation

\section{Financial support and sponsorship}

Nil.

\section{Conflicts of interest}

There are no conflicts of interest.

\section{REFERENCES}

1. Killick DJB. Myrsine africana. The Flowering Plants of Africa 40: t. 1564. South Africa: Government Printer; 1969

2. PlantZAfrica. LiesI Van Der Walt Kirstenbosch National Botanical Garden; 2005. Available from: http://www.plantzafrica.com/plantklm/myrsinafr.htm. [Last cited on 2014 Jun 25]

3. Githiori JB, Höglund J, Waller PJ, Baker RL. Anthelmintic activity of preparations derived from
Myrsine africana and Rapanea melanophloeos against the nematode parasite, Haemonchus contortus, of sheep. J Ethnopharmacol 2002;80:187-91.

4. Kang L, Zhou JX, Shen ZW. Two novel antibacterial flavonoids from Myrsine africana L. Chin J Chem 2007;25:1323-5.

5. Ahmad B, Azam S, Bashir S, Adhikari A, Hussain F. Anti-inflammatory activity and anew compound isolated from aerial parts of Myrsine africana. Afr J Biotechnol 2011;10:8465-70.

6. Abbasi AM, Khan MA, Ahmed M, Zafar M. Herbal medicines used to cure various ailments by the inhabitants of Abbottabad district, North West Frontier Province, Pakistan. Indian $J$ Tradit Knowl 2010;9:175-83.

7. Lee KK, Choi JD. The effects of Areca catechu L extract on anti-aging. Int J Cosmet Sci 1999;21:285-95

8. Mori M, Ikeda N, Kato Y, Minamino M, Watabe K. Inhibition of elastase activity by essential oils in vitro. J Cosmet Dermatol 2002;1:183-7.

9. Bieth J, Spiess B, Wermuth CG. The synthesis and analytical use of a highly sensitive and convenient substrate of elastase. Biochem Med 1974;11:350-7.

10. U.S. Pharmacopoeia-National Formulary. Antimicrobial Effectiveness Testing USP29-NF24. Vol. 1. Ch. 51. Rockville, MD: United States Pharmacopeial Convention, Inc.; 2008. p. 2499.

11. Mukherjee PK, Maity N, Nema NK, Sarkar BK. Bioactive compounds from natural resources against skin aging. Phytomedicine 2011;19:64-73.

12. Tsukahara K, Nakagawa H, Moriwaki S, Takema Y, Fujimura T, Imokawa G. Inhibition of ultraviolet-B-induced wrinkle formation by an elastase-inhibiting herbal extract: Implication for the mechanism underlying elastase-associated wrinkles. Int J Dermatol 2006;45:460-8.

13. Wilson L. Toxic metals and human health. Toxic Metals in Human Health and Disease. $2^{\text {nd }}$ ed Mexico: Eck Institute Nutrition and Bioenergetics; 2012. p. 1-37.

14. Momtaz S, Lall N, Basson A. Inhibitory activities of mushroom tyrosine and DOPA oxidation by plant extracts. S Afr J Bot 2008;74:577-82.

15. Kuete $V$, Efferth $T$. African flora has the potential to fight multidrug resistance of cancer Biomed Res Int 2015;2015:914813 
Copyright of Pharmacognosy Magazine is the property of Wolters Kluwer India Pvt Ltd and its content may not be copied or emailed to multiple sites or posted to a listserv without the copyright holder's express written permission. However, users may print, download, or email articles for individual use. 